\title{
The effect of feed demand on greenhouse gas emissions and farm profitability for organic and conventional dairy farms
}

\author{
Lukas Kiefer, ${ }^{1}$ Friederike Menzel, and Enno Bahrs \\ Department of Farm Management, Schloss Osthof Süd, Hohenheim University, 70593 Stuttgart, Germany
}

\begin{abstract}
The reduction of product-related greenhouse gas (GHG) emissions in milk production appears to be necessary. The reduction of emissions on an individual farm might be highly accepted by farm owners if it were accompanied by an increase in profitability. Using life cycle assessments to determine the product carbon footprints $(\mathrm{PCF})$ and farm-level evaluations to record profitability, we explored opportunities for optimization based on analysis of 81 organic and conventional pasture-based dairy farms in southern Germany. The objective of the present study was to detect common determining factors for low PCF and high management incomes (MI) to achieve GHG reductions at the lowest possible operational cost. In our sample, organic farms, which performed economically better than conventional farms, produced PCF that were significantly higher than those produced by conventional farms [1.61 \pm 0.29 vs. $1.45 \pm 0.28 \mathrm{~kg}$ of $\mathrm{CO}_{2}$ equivalents $\left(\mathrm{CO}_{2} \mathrm{eq}\right)$ per $\mathrm{kg}$ of milk; means $\pm \mathrm{SD})$ ]. A multiple linear regression analysis of the sample demonstrated that low feed demand per kilogram of milk, high grassland yield, and low forage area requirements per cow are the main factors that decrease PCF. These factors are also useful for improving a farm's profitability in principle. For organic farms, a reduction of feed demand of $100 \mathrm{~g} / \mathrm{kg}$ of milk resulted in a PCF reduction of $105 \mathrm{~g}$ of $\mathrm{CO}_{2} \mathrm{eq} /$ $\mathrm{kg}$ of milk and an increase in MI of approximately 2.1 euro cents (c) $/ \mathrm{kg}$ of milk. For conventional farms, a decrease of feed demand of $100 \mathrm{~g} / \mathrm{kg}$ of milk corresponded to a reduction in $\mathrm{PCF}$ of $117 \mathrm{~g}$ of $\mathrm{CO}_{2} \mathrm{eq} / \mathrm{kg}$ of milk and an increase in MI of approximately $3.1 \mathrm{c} / \mathrm{kg}$ of milk. Accordingly, farmers could achieve higher profits while reducing GHG emissions. Improved education and training of farmers and consultants regarding GHG mitigation and farm profitability appear to be the best methods of improving efficiency under traditional and organic farming practices.
\end{abstract}

Received April 24, 2014.

Accepted September 14, 2014.

${ }^{1}$ Corresponding author: Lukas_Kiefer@uni-hohenheim.de
Key words: dairy, greenhouse gas, farm profitability, carbon footprint

\section{INTRODUCTION}

From a global perspective, agriculture is the fourth largest greenhouse gas (GHG) emission source (IPCC, 2007) and accounts for $10.1 \%$ of the overall emissions in the European Union (EEA, 2013). The dairy sector alone is thought to contribute $4 \%$ of global GHG emissions (FAO, 2010). Because emissions due to agriculture are expected to sharply increase quantities of global GHG in the future (Smith et al., 2007), a reduction potential of 5.5 to $6 \mathrm{Gt}$ of $\mathrm{CO}_{2}$ equivalents $\left(\mathbf{C O}_{2} \mathbf{e q}\right.$; Neufeldt et al., 2006) per year until 2030 deserves special attention. Much of agricultural emissions derive from methane emissions of ruminants.

Because pasture accounts for approximately $70 \%$ of the areas used for agriculture globally (FAO, 2013) and can be used for food production by ruminants, pasture makes a considerable contribution to global food security in the framework of milk production (Gill et al., 2010). Compared with increasingly expensive concentrate-based milk production in the recent past, grazing on grassland is a low-cost milk production approach that has attracted increasing interest in Germany (Thomet et al., 2011; Reijs et al., 2013; Kiefer et al., 2014). Investigations into the effects of pasture-based milk production systems on GHG emissions arrive at different results: Lewis et al. (2011) reported pasture to produce less methane emissions than permanent housing. Similarly, Flysjö et al. (2011) observed slightly lower GHG emissions from the pasture systems of New Zealand compared with permanent housing and higher milk yields in Sweden. However, according to Sutter et al. (2013), the weakest aspect of pasture feeding is the high methane emission per kilogram of ECM. To improve the GHG balance in milk production, Brade and Flachowsky (2007), Yan et al. (2010), and Havlik et al. (2014) advocate for increased productivity with higher performance in individual cows, which is usually not found with pasture feeding. Their proposal aims to decrease enteric methane emissions and would necessitate a greater portion of concentrate in the ration (see also Hindrichsen et al., 2006; Christie et al., 2012). 
It is important to note that emissions are influenced by numerous factors, and complex interactions exist between individual sources of emission (Schils et al., 2005; Amon et al., 2006). However, increased efficiency actually appears to be a feasible approach to reducing GHG emissions on the individual farm (Pirlo, 2012). One important factor influencing efficiency and GHG emissions is the amount of feed (forage plus concentrates) that each cow needs to produce $1 \mathrm{~L}$ of milk (Waghorn and Hegarty, 2011).

Against this background, 81 dairy farms in southern Germany with pasture feeding frequently situated in the uplands (a practice that is not representative of the overall milk production in southern Germany) were analyzed economically and for their GHG emissions over 3 economic years (2008-2009 to 2010-2011). To create a high level of acceptance by producers, not only should GHG emissions be reduced, but profitability of milk production should be increased simultaneously (Lovett et al., 2006). Various variables of milk production that can influence GHG emissions and simultaneously influence profitability of the farms were examined as a basis for discussing the following hypotheses: (1) a production-related optimization potential in milk production exists that enables the realization of climate protection with low financial costs of reducing GHG; and (2) specifically, reduced feed demand (forage plus concentrates) per kilogram of milk is a preferable measure to improve GHG balances and increase farm profitability simultaneously.

In this analysis, production by organic and conventional enterprises was considered separately to evaluate the potential differences in production techniques and profitability of the systems.

\section{MATERIALS AND METHODS}

This section describes the method of ascertaining profitability as well as GHG emissions. All of the relevant operational data were collected in cooperation with the farm managers during multiple farm visits.

\section{Sample Description}

The nonrepresentative 81 farms in this study were randomly requested to participate and had to meet the following basic conditions: (1) frequent usage of pasture for dairy cows, (2) location in southern Germany (Baden-Wuerttemberg, Bavaria, and Hesse), (3) a minimum of 25 cows, (4) keeping in loose housing stable indoor systems, and (5) mandatory accounting. On average, these farms were characterized by maintaining a herd of 43 cows. Fleckvieh (34\%), Holstein (31\%), Vorderwälder and Hinterwälder (24\%), Brown
Swiss $(9 \%)$, and other $(2 \%)$ breeds were found. In total, $44 \%$ of the farms operated according to the criteria of organic farming under Council Regulation (EC) No. $834 / 2007$ or under the guidelines of the Naturland and Bioland farming associations (Bioland, 2013; Naturland, 2014). Most cows calved throughout the whole year and only one-third of farmers practiced seasonal calving in spring. The forage ration consisted mainly of pasture grass in summer and grass silage in winter. The land for mowing and pasture was improved grassland and the feed budget per cow and year totaled approximately 5 $\mathrm{t}(\mathrm{DM})$. The average concentrate portion in the ration is approximately 20\%. Additional production-related features of the farms are shown in Table 2.

\section{Data Acquisition and Determination of Selected Efficiency Criteria of Farms}

All material flows (inputs and outputs) relevant to the framework of the present study were quantified during data acquisition of the 81 practicing enterprises and subject to mandatory accounting. Accounting is defined as the complete recording of all of the business transactions based on documents; it provides information to the entrepreneur and is used as a basis for calculating tax liability.

Livestock and any entries and withdrawals or losses of animals were centrally recorded in the animal identification and information database, conducted by the Bavarian State Ministry for Food, Agriculture and Forests. Animal performance data (e.g. milk yield, age at first calving, replacement rate) were taken from reports by state inspection associations for individual farms as well as milk processing plants.

The quantities and ingredients of the purchased feed were recorded based on the bills of feed suppliers. For feed production, necessary input quantities (e.g., diesel, electricity, mineral fertilizers, and pesticides) and their specific emissions were allocated and related to kilograms of $\mathrm{CO}_{2} \mathrm{eq} /$ decitonne $(\mathbf{d t})$ through the cultivation area and yield. The quality of homegrown feed could only be partly verified based on feed analyses. Therefore, the feed ingredient data were partially adopted from data sets of the Agricultural Centre of BadenWuerttemberg (LAZBW, 2009-2011) and Bavarian State Research Centre for Agriculture (LFL, 2012) for the relevant region and respective economic year. Farmland yields were estimated based on information provided by the farm managers and verified through records of nutrient comparisons according to $\S 5$ Fertilizer Ordinance (BMELV, 2012b) and, again, data sets of the Agricultural Center of Baden-Wuerttemberg (LAZBW, 2009-2011) and the Bavarian State Research Center for Agriculture (LFL, 2012). Yields were a function of 
region, altitude, rainfall, mean annual temperatures, livestock count, and general intensity of land management compared with other farms. Regarding grassland yield, all farmland areas (mowing area and pasture) of each individual farm were treated the same because mowing areas and pasture areas were not fixed on most farms within the periods investigated. Feed and energy losses for hay and silage were considered $5 \%$; feed losses on pasture were estimated according to the intensity of pasture usage on the basis of a locally relevant expert network (LAZBW, 2014) with farm-specific values between 10 and $30 \%$. Feed demand per kilogram of milk included all forage (pasture, hay, silage) as well as all concentrates fed.

A 2-step cluster analysis was used for the investigation to subdivide the organic and conventional farms according to their main PCF influencing factor into farms with low, middle, and high feed demand per kilogram of milk. Using this 2-step cluster analysis by the statistical software SPSS (SPSS Inc./IBM Corp. Armonk, NY), the number of clusters was calculated automatically.

Additional purchases (e.g., seeds, pesticides, straw) or sales (animals for slaughter and cash crops) were also recorded based on the farms' accounting data. For all of the means of production purchased within the period under observation, it was assumed that the products were consumed within the same period of time. Modifications were only made when a farmer explicitly noted that stock had been changed for a period beyond that under observation.

\section{Assessment of Farm Profitability}

For assessment of farm profitability, farm-level evaluations of the dairy herd were conducted based on the profit and loss statements of each individual farm. Using this approach, management income (MI) can be calculated on the basis of the profit and loss statement plus the following costs: $5 \%$ interest on capital resources, €15 hourly wage for family workforce, and a local rent estimate for the farmland. Management income is a typical economic parameter used to compare the success of different dairy farms in Germany.

The following economic indicators were considered for farm comparison: profit figures from profit and loss statements, which considered the profit per workforce hour and per farm; MI, which is considered a measure of the complete payment of all production factors (land, labor, and capital); and ground rent per hectare with consideration for wages and interests, which is considered a measure of the farm's ability to pay rent on farmland (Nuthall, 2011).

\section{Modeling of GHG Emissions}

The GHG balances are expressed for each individual farm as a standardized product carbon footprint $(\mathbf{P C F})$, which is related to the production of $1 \mathrm{~kg}$ of milk (De Vries and de Boer, 2009) and can be regarded as part of the life cycle assessment. Regarding life cycle assessment, the standards DIN EN ISO 14040 (ISO, 2006a) and 14044 (ISO, 2006b) form the structural framework of the following 4 phases: goal and scope definition, inventory analysis, impact assessment, and interpretation. The DIN standards are supplemented by the guidelines of the International Dairy Federation (IDF, 2010) and the Intergovernmental Panel on Climate Change (IPCC, 2006a,b) for determining PCF. The directives of the IPCC $(2006 \mathrm{a}, \mathrm{b})$ and of the German Federal Environmental Agency (ProBas, 2013) were used as the database for the emission factors.

The gases were converted into $\mathrm{CO}_{2} \mathrm{eq}$ according to the IPCC (2007) to achieve standardization. This approach modeled the global warming potential for GHG over the next $100 \mathrm{yr}$ as follows: $1 \mathrm{~kg}$ of $\mathrm{CO}_{2} \mathrm{eq} / \mathrm{kg}$ of $\mathrm{CO}_{2}, 25 \mathrm{~kg}$ of $\mathrm{CO}_{2} \mathrm{eq} / \mathrm{kg}$ of $\mathrm{CH}_{4}$, and $298 \mathrm{~kg}$ of $\mathrm{CO}_{2} \mathrm{eq} /$ $\mathrm{kg}$ of $\mathrm{N}_{2} \mathrm{O}$.

The model applied to the GHG balance calculation considered the inputs of the farms, including feed, diesel fuel, electricity, mineral fertilizers, pesticides, and heifers purchased by the farm. The milk and meat products and associated emissions were considered output.

The cradle-to-farm-gate approach in which the accounting of GHG extends only to the milk tank was regarded as the system boundary of milk production. The transport of milk to the dairy factory was beyond the system boundary of the present analysis and disregarded, which was consistent with other studies (e.g., Cederberg and Stadig, 2003; Rotz et al., 2010; O'Brien et al., 2011). The functional unit (FU) of PCF was $1 \mathrm{~kg}$ of fat- and protein-corrected milk (FPCM), which was standardized according to the IDF (2010).

Based on recommendations by the IDF (2010), the apportionment of emissions between milk and meat in this paper was through physical allocation, which was based on the relationship between feed energy of the cow and its production of milk and meat using the following formula:

$$
\mathrm{AF}=1-5.7717 \times \mathrm{R},
$$

where $\mathrm{AF}=$ allocation factor milk, and $\mathrm{R}=$ amount of beef ( $\mathrm{kg}$ of live weight)/amount of milk ( $\mathrm{kg}$ of FPCM). Accordingly, approximately $77 \%$ of emissions were attributed to milk, whereas the remaining percentage represented the PCF of the associated meat production. 
Greenhouse gas emissions are usually differentiated between primary and secondary sources of emissions (Rotz et al., 2010; Zehetmeier et al., 2012). Primary sources include emissions produced on the farm, whereas secondary emissions may be produced upstream from the farm.

Primary Sources of Emissions. Primary sources include methane emissions caused by enteric fermentation, methane and nitrous oxide emissions by storage of organic fertilizers (e.g., slurry, liquid manure, dung, feed residues, straw), nitrous oxide and $\mathrm{CO}_{2}$ emissions originating from fertilizer application and liming, and nitrous oxide emissions from pastures. Methane emissions from dairy cattle by enteric fermentation and $\mathrm{CH}_{4}$ emissions originating from slurry storage were calculated by the Tier- 2 method described in IPCC (2006a; equations 10.21 and 10.23).

Nitrous oxide emissions caused by storage of liquid manure were calculated using the Tier-1 method (IPCC, 2006a; equations 10.25 and 10.26). These emissions also included the direct and indirect emissions produced by volatilization. To calculate the average $\mathrm{N}$ excretion, an excretion rate of 0.48 ( 0.33 for calves) $\mathrm{kg}$ of $\mathrm{N}$ per 1,000 $\mathrm{kg}$ of live weight per day for dairy cattle was assumed (IPCC, 2006a; Table 10.19). For direct nitrous oxide emissions, the emission factor was the weighted average of the respective storage systems. A weighted average was also constructed for determining the $\mathrm{N}_{2} \mathrm{O}$ emissions produced indirectly through volatilization $\left(\mathrm{NH}_{3}\right.$ and $\mathrm{NO}_{\mathrm{x}}$; IPCC, 2006a; Table 10.22).

Furthermore, the amount of nitrogen available for application after storage loss was calculated (IPCC, 2006a; Table 10.23). For the quantity of N applied through the litter contained in the farm fertilizer, values of $7 \mathrm{~kg} / \mathrm{yr}$ (cows) and $4 \mathrm{~kg} / \mathrm{yr}$ (calves) were assumed (IPCC, 2006a).

For fertilizer application, direct and indirect emissions were also considered and calculated by means of the Tier-1 method based on overall $\mathrm{N}$ application through mineral and farm fertilizer as well as plant residue. The IPCC (2006b; Table 11.1) specified an emission factor of $0.01 \mathrm{~kg}$ of $\mathrm{N}_{2} \mathrm{O}-\mathrm{N} / \mathrm{kg}$ of $\mathrm{N}$ application for direct emissions and $0.02 \mathrm{~kg}$ of $\mathrm{N}_{2} \mathrm{O}-\mathrm{N} / \mathrm{kg}$ of $\mathrm{N}$ for manure deposited by livestock during pasture.

Indirect $\mathrm{N}_{2} \mathrm{O}$ emissions during application developed through atmospheric deposition, which accounted for an emission factor of $0.01 \mathrm{~kg}$ of $\mathrm{N}_{2} \mathrm{O}-\mathrm{N} /\left(\mathrm{kg}\right.$ of $\mathrm{NH}_{3}-\mathrm{N}$ + NOx-N) according to IPCC (2006b; Table 11.3). In addition to farm and pasture manure $\left(0.2 \mathrm{~kg}\right.$ of $\mathrm{NH}_{3}-\mathrm{N}$ and $\mathrm{NOx}-\mathrm{N}$ per $\mathrm{kg}$ of $\mathrm{N}$ ), the nitrogen portion produced by mineral fertilizer $\left(0.1 \mathrm{~kg}\right.$ of $\mathrm{NH}_{3}-\mathrm{N}$ and $\mathrm{NO}_{\mathrm{x}}-\mathrm{N}$ per $\mathrm{kg}$ of $\mathrm{N}$ ) that volatilized as $\mathrm{NH}_{3}$ and $\mathrm{NO}_{\mathrm{x}}$ was also considered.
However, indirect nitrous oxide emissions also developed through leaching. The IPCC (2006b; Table 11.3) indicated an emission factor of $0.0075 \mathrm{~kg}$ of $\mathrm{N}_{2} \mathrm{O}-\mathrm{N}$ per $\mathrm{kg}$ of eluviated nitrogen. In addition, the nitrogen portion lost by eluviation was rated $0.3 \mathrm{~kg}$ of $\mathrm{N} / \mathrm{kg}$ of $\mathrm{N}$ applied or produced by pasture manure. The nitrogen emission factor of the IPCC (2006b; Table 11.1) for "temperate organic crop and grassland soils" was $8 \mathrm{~kg}$ of $\mathrm{N}_{2} \mathrm{O} /$ ha per year and was used for all of the farm areas.

The quantity of livestock excrements was apportioned between the number of grazing days, average number of hours on pasture, and storage plus application of liquid manure. The lime requirement was calculated based on the needs of the plant, which was dependent on the yield and an emission factor of $0.12 \mathrm{t}$ of carbon per $\mathrm{t}$ of lime application (assumed) according to the IPCC (2006b).

Secondary Sources of Emissions. Emissions caused by production of electricity, fuel, mineral fertilizers, pesticides, and purchased feed fall into the scope of secondary sources. To calculate secondary emissions, the emission factors of the ProBas database of the Federal Environment Agency (ProBas, 2013) were considered, and the most suitable process (related to the geographic location and year of investigation of the production method described) was selected.

The emission factors of the main secondary sources are listed in Table 1. The IDF (2010) advocates for consideration of emissions caused by direct changes in land use that result from the conversion of natural areas and pastures into plough land (Weiss and Leip, 2012). Therefore, emission factors for purchased feedstuffs (grain maize, crop, rapeseed meal, and soy meal) that were frequently produced overseas were associated with direct changes in land use. However, the direct changes in land use for feed mainly produced in Germany, including grass silage, dried molasses, or field beans, cannot be traced. If a compound feed was used, it was broken down by ingredient and assessed proportionately with the emission factors of the ingredients with consideration of the direct changes in land use. When allocation was required for the purchased feedstuff, it was economically separated into main and side products, which was consistent with other studies (Yan et al., 2011). For rearing heifers as a means of replacement, emissions of $11 \mathrm{~kg}$ of $\mathrm{CO}_{2} \mathrm{eq} / \mathrm{kg}$ of live weight were assumed, independent of the farming system (Rotz et al., 2010) and multiplied by the corresponding replacement rate. The average weight calculated for these heifers was determined in cooperation with the farm managers and based on breed: Fleckvieh $=630 \mathrm{~kg}$, Holstein $=580 \mathrm{~kg}$, Vorderwälder $=550 \mathrm{~kg}$, 
and Brown Swiss $=580 \mathrm{~kg}$. These 4 breeds can be ordered in regard to their influence on milk or meat output as follows (with decreasing breed influence on milk yield compared with meat yield): Holstein, Brown Swiss, Vorderwälder, and Fleckvieh (Elfrich and Roesicke, 2012). Emissions with effects $<1 \%$ of the overall emissions (e.g., manufacture of cleaning agents, drugs) were not considered for the balance according to the IDF (2010), and the emission-neutral biogenic carbon cycle of breathing and photosynthesis was also disregarded. Investment goods that can be used for many years (such as buildings, machinery, storage of liquid manure, housing systems, and equipment for the application of liquid manure) and that cannot be identified in the flow of materials for immediate use were not considered. This method is in accordance with the IDF (2010) because these emissions accounted for a small portion of product-related emissions and data acquisition in this area is complex.

\section{RESULTS}

According to the stated hypotheses, the first step of the present analysis was intended to describe the influence of various variables on the PCF per kilogram of milk and the method in which these influencing factors co-determined a farm's profitability. All of the factors that potentially influence the PCF were considered explicitly, whereas the variables that predominantly determined profitability and had negligible influences on the PCF (e.g., work economics and milk price) were

Table 1. Emission factors of selected secondary sources of greenhouse gases (ProBas, 2013)

\begin{tabular}{lc}
\hline Item & $\begin{array}{c}\text { Emission factor } \\
\left(\mathrm{kg} \text { of } \mathrm{CO}_{2} \text { eq/unit }\right)\end{array}$ \\
\hline Electricity (kWh) & 0.57 \\
Diesel fuel consumption (L) & 2.98 \\
Mineral fertilizer production (kg) & \\
$\mathrm{N}$ & 7.57 \\
$\mathrm{P}_{2} \mathrm{O}_{5}$ & 1.25 \\
$\mathrm{~K}_{2} \mathrm{O}$ & 1.2 \\
$\mathrm{Ca}$ & 0.01 \\
Pesticides & 5.37 \\
Purchased feed (kg) & \\
Grain maize (dLUC $\left.{ }^{1}\right)$ & 0.31 \\
Crop (dLUC) & 0.41 \\
Rapeseed meal (dLUC) & 0.38 \\
Soy meal (dLUC) & 0.50 \\
Field bean & 0.14 \\
Dried molasses & 0.03 \\
Grass silage & 0.10 \\
Maize silage & 0.10 \\
Hay & 0.14 \\
Clover & 0.12 \\
Field grass & 0.04 \\
Mineral feed & 0.01 \\
\hline
\end{tabular}

${ }^{1}$ Consideration of direct land use changes (dLUC) for purchased feed. not considered. The coefficient of determination $\left(\mathrm{R}^{2}\right)$ of 0.367 for organic farms between the PCF and MI per kilogram of milk indicated that a relationship existed between GHG balance and farm profitability on principle. This relationship was less pronounced for conventional farms, which had a coefficient of determination of only 0.193 .

In a second step, the correlation between PCF and profitability was closely investigated, with special consideration given to the feed demand per kilogram of milk as an important indicator of efficiency.

\section{Potential Factors Influencing PCF and Associated Correlation with MI}

To identify factors that have the potential to influence the PCF level, we selected 11 variables from the farm production methods that may influence the PCF in consideration of comparable studies (e.g., Jones et al., 2014). Table 2 shows the variables for organic (36 farms) and conventional (45 farms) farming. Differences between the production methods were recognizable, particularly in regard to diesel fuel consumption, milk yield, replacement rate, concentrated feed use, and total feed demand per kilogram of milk. The conventional milk production achieved lower $(P=0.014) \mathrm{PCF}$ compared with organic production $(1.45 \pm 0.28$ vs. 1.61 $\pm 0.29 \mathrm{~kg}$ of $\mathrm{CO}_{2} \mathrm{eq} / \mathrm{kg}$ of milk; mean $\pm \mathrm{SD}$ ).

In the next step, we compared the coefficients of determination for the 11 selected variables to the PCF and MI per kilogram of milk of the organic and conventional farms to allow for preliminary assessment of the importance of single influencing factors. Table 3 indicates that the demand of feed per kilogram of milk, milk yield per cow, feed area available per cow, grassland level of yield, and replacement rate had the greatest effect on the PCF.

The coefficients of determination of the variables presented with the MI were smaller than those with the PCF. However, marked relationships existed among the variables listed in Table 3, particularly in regard to the effect of feed demand per kilogram of milk and milk yield per cow on MI. This finding demonstrates that the potential should exist to optimize GHG balances and farm profitability simultaneously.

In a third step, we analyzed the 11 variables and production method (organic versus conventional) as the 12 th variable by means of a multiple linear regression (Backhaus et al., 2008) to identify the statistically significant factors among those that have the potential to influence the PCF (see Table 4). The factor milk yield was not considered in the regression analysis because it had a correlation of 0.82 with the factor feed demand per kilogram of milk. 
Table 2. Factors in the sample that have the potential to influence the carbon footprint for organic and conventional farming

\begin{tabular}{|c|c|c|c|c|c|c|c|c|}
\hline Variable & \multicolumn{4}{|c|}{ Organic } & \multicolumn{4}{|c|}{ Conventional } \\
\hline Carbon footprint $\left(\mathrm{CO}_{2} \mathrm{eq} / \mathrm{kg}\right.$ of milk) & 1.61 & 0.29 & 1.18 & 2.38 & 1.45 & 0.28 & 1.06 & 2.59 \\
\hline Grassland yield level (dt/ha) & 63 & 16 & 39 & 92 & 67 & 18 & 39 & 115 \\
\hline Forage area (ha/cow $)$ & 1.0 & 0.3 & 0.6 & 1.8 & 1.0 & 0.4 & 0.5 & 2.1 \\
\hline Mineral N (kg/ha) & & & & & 23 & 16 & 0 & 77 \\
\hline First calving age (mo) & 31.0 & 2.7 & 24.8 & 36.9 & 30.2 & 2.3 & 26.1 & 37.4 \\
\hline Concentrate (dt/cow) & 8.7 & 4.0 & 0.2 & 18.9 & 15.1 & 7.0 & 1.4 & 31.1 \\
\hline Feed demand ( $\mathrm{kg} / \mathrm{kg}$ of milk) & 1.13 & 0.20 & 0.84 & 1.82 & 1.01 & 0.16 & 0.80 & 1.64 \\
\hline
\end{tabular}

Feed demand per kilogram of milk was the main characteristic with a coefficient of determination of regression of 0.735 , and it was followed by replacement rate, grassland yield level, and area available per cow. Nevertheless, if the factors were considered separately, milk yield per cow (0.407) had the second highest coefficient of determination after feed demand per kilogram of milk (0.516).

The negative correlation of replacement rate is indicative of a lower PCF in cases of high replacement rates, although this result indicates that more animals are required for stock replacement. The explanation is that in our sample farms with high replacement rates are also characterized by high milk yields and low feed demands per kilogram of milk, which are the most important factors affecting PCF. But it must be stated that causality of replacement rates and PCF is not implied necessarily and different results might be found in other studies.

All of the significant influencing factors help explain why conventional farms performed better when compared with organic farms (Table 2); conventional farms were characterized by lower feed demand per kilogram of milk, higher replacement rates, higher grassland yield, and less area used per cow, despite the absence of the production method in the results of the multiple linear regression analysis. Similarly, the milk yield per cow factor indicates that conventional farms performed better. A fourth step examined the individual farms' composition of PCF between organic and conventional farming with a focus on the feed demand per kilogram of milk because this factor (together with the milk yield per cow) was found to be the main factor influencing for the PCF as well as the MI.

\section{Size and Composition of PCF According to the Sample Based on Feed Demand}

Figures 1 and 2 represent the PCF of all the organic and conventional farms, respectively. We sorted the 2 production methods by feed demand per kilogram of milk with ascending figures from left to right. The diagrams demonstrate that both production methods tended to have high PCF when the feed demand per

Table 3. Coefficients of determination of single variables regarding their effect on the carbon footprint and management income (MI) per kilogram of milk for organic (ORG) and conventional (CONV) farms in the sample

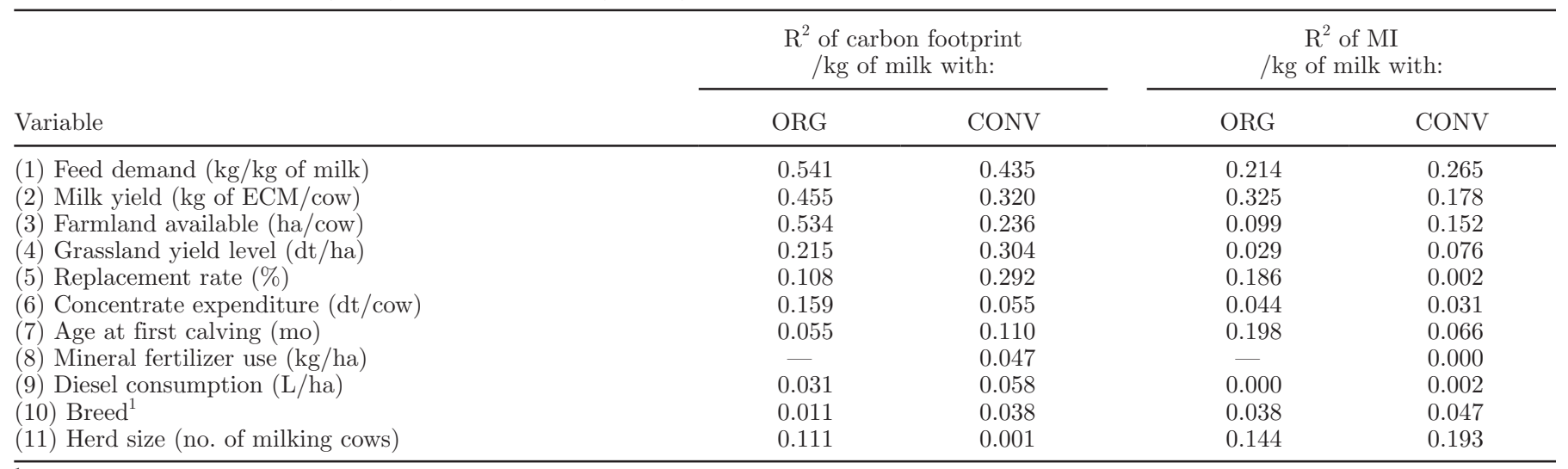

${ }^{1}$ Breed sorting via dummy variables according to their influence on milk yield in the breeds: Holstein $=1 ;$ Brown Swiss $=2 ;$ Vorderwälder $=$ $3 ;$ and Fleckvieh $=4$. 
Table 4. Multiple linear regression ${ }^{1}$ analysis to identify the significant factors influencing the carbon footprints per kilogram of milk in the sample $\left(\mathrm{R}^{2}=0.735 ; \mathrm{SE}=0.156\right)$

\begin{tabular}{|c|c|c|c|c|c|}
\hline \multirow[b]{2}{*}{ Item } & \multicolumn{2}{|c|}{$\begin{array}{l}\text { Nonstandardized } \\
\text { coefficients }\end{array}$} & \multirow{2}{*}{$\frac{\begin{array}{c}\text { Standardized } \\
\text { coefficients }\end{array}}{\beta^{5}}$} & \multirow[b]{2}{*}{$t^{2}$} & \multirow[b]{2}{*}{$\mathrm{Sig}^{3}$} \\
\hline & $\mathrm{B}^{4}$ & SE & & & \\
\hline Feed demand $(\mathrm{kg} / \mathrm{kg}$ of milk) & 0.734 & 0.118 & 0.465 & 6.234 & 0.000 \\
\hline Replacement rate $(\%)$ & -0.010 & 0.002 & -0.301 & -4.469 & 0.000 \\
\hline Grassland yield level (dt/ha) & -0.004 & 0.001 & -0.251 & -3.283 & 0.002 \\
\hline Farmland per cow (ha) & 0.129 & 0.055 & 0.199 & 2.333 & 0.022 \\
\hline Constant & 1.150 & 0.169 & & 6.811 & 0.000 \\
\hline
\end{tabular}

${ }^{1}$ The linearity, multicollinearity, heteroscedasticity, and normal distribution conditions of the disturbance variables were considered.

${ }^{2} t=$ relative importance of each value to the model.

${ }^{3} \mathrm{Sig}=$ level of significance.

${ }^{4} \mathrm{~B}=\mathrm{y}$-intercept of the estimated regression model.

${ }^{5} \beta=$ association of the independent variable with the dependent variable.

kilogram of milk increased. We observed significant variance within the sample, with the lowest PCF found for the organic farms being less than half the highest $\mathrm{PCF}$ value.

Moreover, the 2 figures demonstrate that digestion (methane), rearing of heifers (despite low PCF with high replacement rates), and growing of feed (pasture, grass silage, maize silage, and hay) constitute the major portion of the PCF. The differences between farms with high and low PCF appear to be mainly a result of forage usage.

\section{Relationship Between PCF and Farm Profitability with Special Consideration of Feed Demand}

The average feed demand per kilogram of milk was $1.13 \pm 0.20 \mathrm{~kg}$ of feed $/ \mathrm{kg}$ of milk for organic farms and $1.01 \pm 0.16 \mathrm{~kg}$ of feed $/ \mathrm{kg}$ of milk for conventional farms

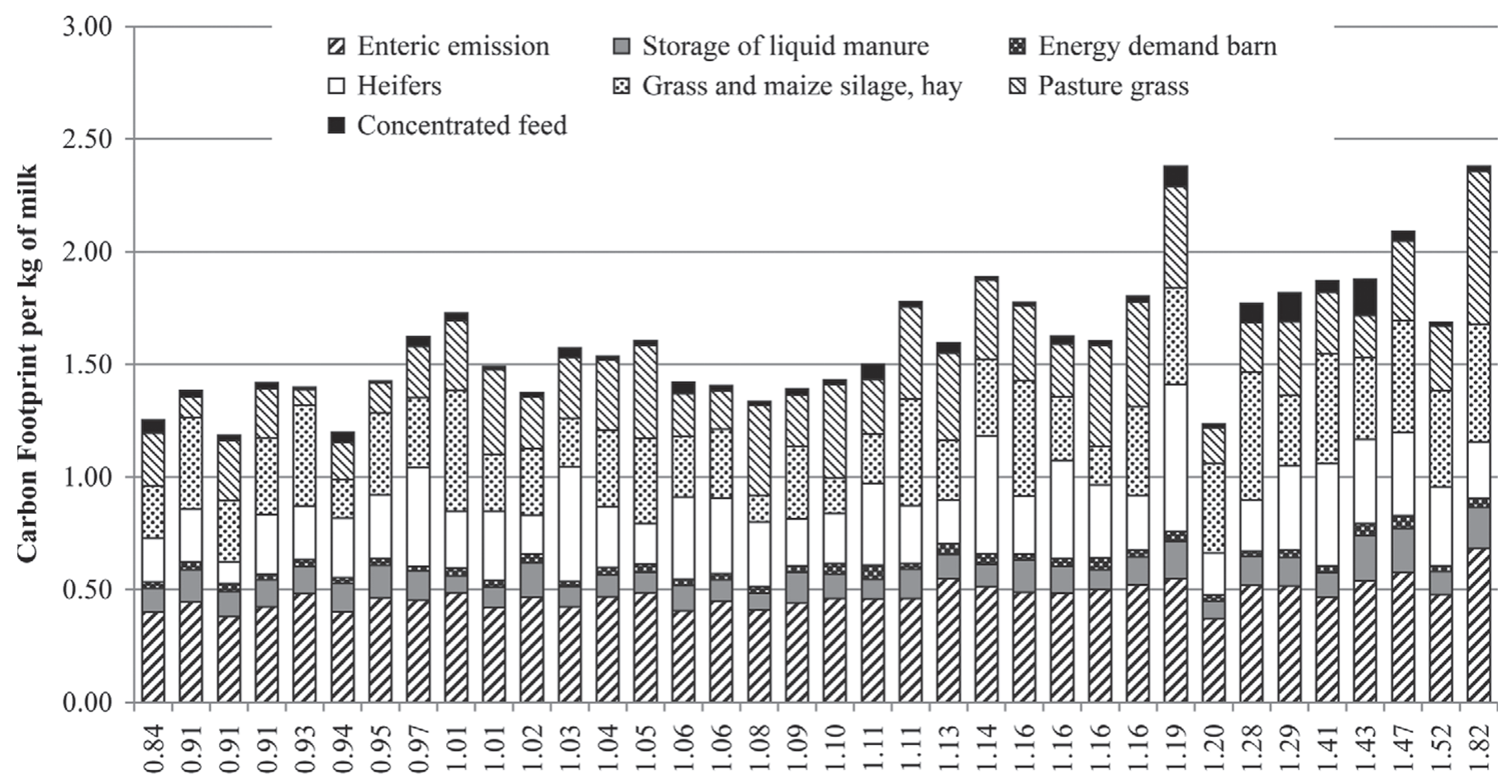

Feed demand per kg of milk

Figure 1. Composition of the carbon footprint $\left(\mathrm{CO}_{2}\right.$ equivalents $/ \mathrm{kg}$ of milk) for the organic farms in the sample sorted by feed demand (kg/ $\mathrm{kg}$ of milk) with ascending values from left to right. 


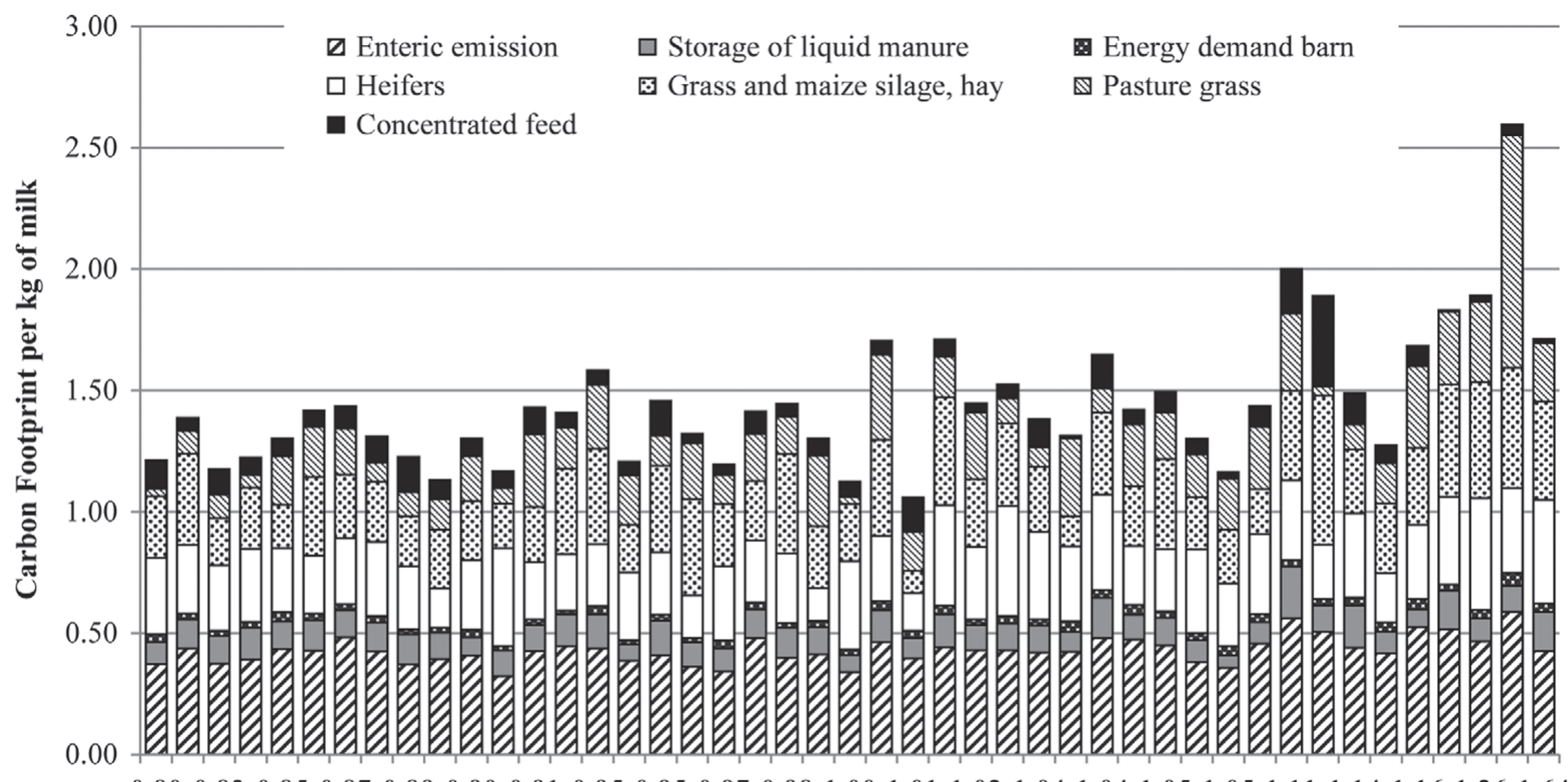

Feed demand per $\mathrm{kg}$ of milk

Figure 2. Composition of carbon footprint $\left(\mathrm{CO}_{2}\right.$ equivalents $/ \mathrm{kg}$ of milk) for the conventional farms in the sample sorted by feed demand $(\mathrm{kg} / \mathrm{kg}$ of milk) with ascending values from left to right.

(Table 5). We found differences in the PCF within one production method for each cluster of feed demand $(P$ $<0.01)$. For both production methods, farms with lower feed demand per kilogram of milk tended to feature larger farms, higher yield per hectare, lower farmland use per cow, higher milk quantities, and higher forage performance. Moreover, they had higher concentrate expenditures and replacement rates, which substantiated the results of the multiple linear regression analysis. Regarding grazing hours, results were inconsistent, which indicated that low feed demand per kilogram of milk was not necessarily dependent on the number of grazing hours. These results should not be generalized, however, because the sample or the individual clusters were not based on a large number of representative farms (see Table 5).

The review of farm profitability reveals major advantages for organic farms compared with conventional farms (see also Kiefer et al., 2014). In addition, farms with low feed demand per kilogram of milk were generally characterized by lower feed costs, direct costs, and full cost of milk production, and they achieved better MI or higher ground rents and profits per workforce hour or farm for this reason. Therefore, feed demand per kilogram of milk could serve as an indicator of efficiency, although the above observations cannot be ascribed solely to this particular factor.
The data for the individual farms resulted in the following linear regression equations for the effect of fodder demand per kilogram of milk on the $\mathrm{PCF} / \mathrm{kg}$ of milk and MI. For organic farms, PCF: $\mathrm{y}=1.05 \mathrm{x}+$ 0.42 ; and MI: $\mathrm{y}=-20.67 \mathrm{x}+18.36$. For conventional farms, PCF: $\mathrm{y}=1.17 \mathrm{x}+0.26$; and MI: $\mathrm{y}=-31.04 \mathrm{x}$ +16.35 .

The results indicate that for organic farms, the reduction of feed demand per kilogram of milk by $100 \mathrm{~g}$ enables a PCF reduction of $105 \mathrm{~g}$ of $\mathrm{CO}_{2} \mathrm{eq}$ per $\mathrm{kg}$ of milk and an increase in MI of approximately 2.1 euro cents $/ \mathrm{kg}$ of milk. For conventional farms, the reduction of feed demand per kilogram of milk by $100 \mathrm{~g}$ corresponded to a PCF reduction of $117 \mathrm{~g}$ of $\mathrm{CO}_{2} \mathrm{eq} / \mathrm{kg}$ of milk and an increase in MI by approximately 3.1 cents/ $\mathrm{kg}$. Increased MI/ $\mathrm{kg}$ of milk also resulted in an accretion of many other economic characteristics, including profits, which were not considered here. However, for the conventional farms in our sample, the linear regression equation for MI was strongly influenced by the results of 3 outlier farms.

Therefore, our hypotheses can be largely confirmed, with feed demand per kilogram of milk recognized as a central factor in the potential improvement of the PCF and profitability of farms. Similarly, these results could be reproduced for the milk yield and area per cow characteristics but with decreasing coefficients of 


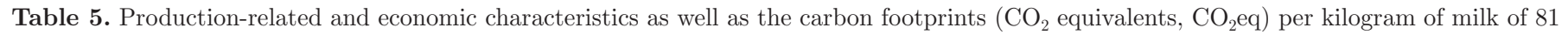
dairy farms in southern Germany with grazing for organic and conventional farms as well as by different feed demand values per kilogram of milk using the k-means cluster analysis (mean values)

\begin{tabular}{|c|c|c|c|c|c|c|}
\hline \multirow[b]{2}{*}{ Item } & \multicolumn{3}{|c|}{ Organic } & \multicolumn{3}{|c|}{ Conventional } \\
\hline & 1 & 2 & 3 & 1 & 2 & 3 \\
\hline Feed demand ( $\mathrm{kg} / \mathrm{kg}$ of milk) & 0.98 & 1.16 & 1.53 & 0.90 & 1.08 & 1.55 \\
\hline $\mathrm{SD}$ & 0.07 & 0.06 & 0.17 & 0.06 & 0.07 & 0.13 \\
\hline Number of farms & 16 & 15 & 5 & 22 & 21 & 2 \\
\hline Herd size (milking cows) & 51 & 39 & 39 & 43 & 42 & 28 \\
\hline Grassland yield level (dt of DM/ha) & 64 & 62 & 58 & 65 & 71 & 42 \\
\hline Milk yield (kg of ECM/cow) & 6,761 & 5,355 & 4,295 & 7,517 & 5,869 & 3,393 \\
\hline Milk yield from forage ( $\mathrm{kg}$ of ECM/cow) & 4,567 & 3,817 & 3,147 & 3,690 & 3,350 & 2,670 \\
\hline Concentrated feeds (dt/cow) & 10.7 & 7.5 & 5.6 & 18.8 & 12.4 & 3.6 \\
\hline Grazing hours per cow and year & 2,435 & 2,971 & 1,976 & 1,727 & 2,708 & 3,080 \\
\hline Replacement rate $(\%)$ & 27.3 & 23.4 & 24.3 & 36.8 & 32.2 & 27.4 \\
\hline Carbon footprint ( $\mathrm{kg}$ of $\mathrm{CO}_{2} \mathrm{eq} / \mathrm{kg}$ of milk) & $1.44^{\mathrm{a}}$ & $1.66^{\mathrm{b}}$ & $1.98^{\mathrm{c}}$ & $1.32^{\mathrm{a}}$ & $1.51^{\mathrm{b}}$ & $2.15^{\mathrm{c}}$ \\
\hline Management income (MI; $\phi / \mathrm{kg}$ of milk) & -0.6 & -6.2 & -15.2 & -12.6 & -15.8 & -36.5 \\
\hline Ground rent $(€ /$ ha $)$ & 122 & -58 & -181 & -571 & -584 & -452 \\
\hline Earnings/workforce hour $(€)$ & 22.91 & 18.96 & 12.24 & 11.09 & 10.70 & 5.95 \\
\hline Earnings/farm $(€)$ & 73,793 & 49,703 & 35,874 & 38,634 & 33,106 & 18,540 \\
\hline
\end{tabular}

${ }^{\mathrm{a}-\mathrm{c}}$ Means within a row and within the organic or conventional production method with different superscripts differ $(P<0.01)$.

determination. Other single production-related characteristics reviewed in this study were unsuitable for achieving simultaneous optimization of GHG balances and farm profitability. However, dependency only applies if the results of either production method (organic vs. conventional) are reviewed separately.

\section{DISCUSSION}

Efforts to improve efficiency have shown that consideration of PCF revealed somewhat better values for more efficient conventional milk production in this sample, although the differences between individual farms within one production method outweighed the differences between the production methods. With average values of $1.45 \mathrm{~kg}$ of $\mathrm{CO}_{2} \mathrm{eq} / \mathrm{kg}$ of milk for conventional production and $1.61 \mathrm{~kg}$ of $\mathrm{CO}_{2} \mathrm{eq} / \mathrm{kg}$ of milk for organic production, the results of this study showed markedly higher $\mathrm{PCF}$ values than the respective results of most other studies, which found PCF values in the range of 0.8 to $1.3 \mathrm{~kg}$ of $\mathrm{CO}_{2} \mathrm{eq} / \mathrm{kg}$ of milk without regard to their methodological details (Pirlo, 2012). In other studies investigating GHG emissions, organic and conventional farms performed at comparable levels (Thomassen et al., 2008; Van der Werf et al., 2009; Kristensen et al., 2011).

The feed demand per kilogram of milk had the highest influence on PCF in our study. Thomassen et al. (2009) also advocate for the efficient feed input per kilogram of milk, among other factors, to enable profitable and environmentally friendly production. Various approaches are designed to reduce feed demand, and influencing factors include the composition of feed (relation of forage and concentrated feed), area available per cow, digestibility and tastiness of feed, herd composition, and phase of vegetation (Dryder, 2008). Highquality feed with high energy content and relatively low fiber content simultaneously reduces the feed demand per kilogram of milk and PCF (Lovett et al., 2008). Lovett et al. (2006) demonstrate that an increased concentrate portion results in decreasing GHG emissions within a breed-dependent milk yield level because the increase in concentrated feed reduces enteric methane production (Hindrichsen et al., 2006; Yan et al., 2010). O'Brien et al. (2010) also found a lower concentrateassociated PCF of milk compared with pasture-based milk production. However, the methane production formula recommended by the IPCC (2006a) does not yet consider this correlation. The fact that concentrated feed consists of materials that are digestible by humans is also a point of criticism because it may be disadvantageous in the context of feed competition as a result of increasing population numbers (Gill et al., 2010). Furthermore, a major portion of such feed (e.g., soy meal) is produced overseas and can lead to changes in land use in the countries of origin (Weiss and Leip, 2012), the effect of which on the global GHG balance has not yet been determined conclusively.

Kristensen et al. (2011) consider production systems that focus on high herd efficiency advantageous and state that feed conversion rate (conversion of feed into milk) and milk yield are major factors that indicate success. Other studies (e.g., Brade and Flachowsky, 2007; Yan et al., 2010) also consider an increase in milk yield per cow to be an important strategy of PCF reduction as a result of lower methane emissions per kilogram of milk. High milk yield is frequently linked to high replacement rates in the literature because high 
milk yield is often negatively correlated with fertility (Lovett et al., 2006; Yan et al., 2010). This can lead to higher PCF, because more heifers for replacement must be reared. Thus, Casey and Holden (2005) consider the combination of a milk yield increase per cow and decrease of young cattle rearing (low replacement rate) to be a suitable strategy to lower the PCF. However, the results of our study call into question to what extent the simultaneous optimization of these 2 variables is possible because when the characteristics of milk yield and replacement rate are compared, the effects of higher milk yield or better feed conversion ratio, respectively, appear to outweigh the emissions of rearing young cattle. Obviously, some threshold exists where gains in yield can compensate for higher replacement rates, but equally it is manifest that lower replacement rates reduce GHG emissions from rearing heifers.

Overall, these considerations show that an isolated view of individual sources of emissions can lead to undesirable outcomes. Therefore, efficient reduction strategies should be based on the individual farm level to arrive at an economic and PCF-related management optimum that combines the above criteria in the context of herd efficiency. A holistic perspective is required to avoid reducing the efficiency of the entire food chain by an overemphasis on savings of the individual farm.

\section{CONCLUSIONS}

A comparative analysis demonstrated that efficiently managed milk production (high herd efficiency) in particular creates the potential for the simultaneous optimization of farm income and GHG balances. The efficiency criteria found in this study (including feed demand per kilogram of milk, milk yield per cow, grassland yield, and area per cow) appear to be factors that indicate the success of farm management. An isolated consideration of individual variables is not expedient for determining the reduction potential because every reduction measure causes changes in the overall system. The improved education and training of farmers and consultants regarding GHG mitigation appears to be a suitable measure for reducing GHG emissions on a national level. Only well-trained farm managers are good managers capable of running their farms efficiently. If reducing GHG emissions can result in higher profits, an education-induced intrinsic motivation to improve management might be more expedient than additional regulations, laws, or taxes on GHG emissions.

\section{ACKNOWLEDGMENTS}

The Ministry of Rural Affairs and Consumer Protection Baden-Wuerttemberg (Germany) have funded this research work. Additionally, the authors thank the H. Wilhelm Schaumann Stiftung (Hamburg, Germany) for their financial support.

\section{REFERENCES}

Amon, B., V. Kryvoruchko, T. Amon, and S. Zechmeister-Boltenstern. 2006. Methane, nitrous oxide and ammonia emissions during storage and after application of dairy cattle slurry and influence of slurry treatment. Agric. Ecosyst. Environ. 112:153-162.

Backhaus, K., B. Erichson, W. Plinke, and R. Weiber. 2008. Multivariate Analysemethoden. Springer-Verlag, Berlin, Germany.

Bioland. 2013. Bioland-Richtlinien. http://www.bioland.de/fileadmin/ bioland/file/bioland/qualitaet_richtlinien/Bioland_Richtlinien_ 18_März_2013.pdf.

BMELV. 2012b. Verordnung über die Anwendung von Düngemitteln, Bodenhilfsstoffen, Kultursubstraten und Pflanzenhilfsmitteln nach den Grundsätzen der guten fachlichen Praxis. Düngeverordnung. Artikel 5 Absatz 36 des Gesetzes vom 24. Februar 2012 (BGBl. I S. 212). BMELV, Berlin, Germany.

Brade, W., and G. Flachowsky. 2007. Potenziale zur Reduzierung der Methanemissionen bei Wiederkäuern. Zuchtungskunde 79:417465.

Casey, J. W., and N. M. Holden. 2005. Analysis of greenhouse gas emissions from the average Irish milk production system. Agric. Syst. 86:97-114.

Cederberg, C., and M. Stadig. 2003. System expansion and allocation in life cycle assessment of milk and beef production. Int. J. Life Cycle Assess. 8:350-356.

Christie, K. M., C. J. P. Gourley, R. P. Rawnsley, R. J. Eckard, and I. M. Awty. 2012. Whole-farm systems analysis of Australian dairy farm greenhouse gas emissions. Anim. Prod. Sci. 52:998-1011.

De Vries, M., and I. J. M. de Boer. 2009. Comparing environmental impacts for livestock products: A review of life cycle assessments. Livest. Sci. 128:1-11.

Dryder, G. McL. 2008. Animal Nutrition Science. Cambridge University Press, Cambridge, UK.

EEA (European Environment Agency). 2013. Greenhouse gas data viewer. EEA, Copenhagen, Denmark.

Elfrich, A., and E. Roesicke. 2012. Rinderrassen. aid infodienst. 2. Auflage, aid infodienst of Ernährung, Landwirtschaft, Verbraucherschutz e.V., Bonn, Germany.

FAO. 2010. Greenhouse gas emissions from the dairy sector: A life cycle assessment. Food and Agriculture Organization of the United Nations (FAO), Animal Production and Health Division, Rome, Italy.

FAO. 2013. FAO Statistical Yearbook 2013: World food and agriculture. Food and Agriculture Organization of the United Nations (FAO), Rome, Italy.

Flysjö, A., M. Henriksson, C. Cederberg, S. F. Ledgard, and J. E. Englund. 2011. The impact of various parameters on the carbon footprint of milk production in New Zealand and Sweden. Agric. Syst. 104:459-469.

Gill, M., P. Smith, and J. M. Wilkinson. 2010. Mitigating climate change: The role of domestic livestock. Animal 4:323-333.

Havlik, P., H. Valin, M. Herrero, M. Obersteiner, E. Schmid, C.M. Rufino, A. Mosnier, P.K. Thornton, H. Böttcher, R.T. Conant, S. Frank, S. Fritz, S. Fuss, F. Kraxner, and A. Notenbaert. 2014. Climate change mitigation through livestock system transitions. Proc. Natl. Acad. Sci. USA 111:3709-3714.

Hindrichsen, I. K., H. R. Wettstein, A. Machmüller, and M. Kreuzer. 2006. Methane emission, nutrient degradation and nitrogen turnover in dairy cows and their slurry at different milk production scenarios with and without concentrate supplementation. Agric. Ecosyst. Environ. 113:150-161.

IDF. 2010. A common carbon footprint approach for dairy. The IDF Guide to Standard Lifecycle Assessment Methodology for the Dairy Sector. Bull. No. 445. International Dairy Federation, Brussels, Belgium. 
IPCC. 2006a. Emissions from livestock and manure management. In Guidelines for National Greenhouse Gas Inventories. Vol. 4: Agriculture, Forestry and Other Land Use. H. S. Eggleston, L. Buendia, K. Miva, T. Ngara, and K. Tanabe, ed. National Greenhouse Gas Inventories Program, Institute for Global Environmental Strategies (IGES), Japan, 11.5-11.4. IPCC, Geneva, Switzerland.

IPCC. 2006b. $\mathrm{N}_{2} \mathrm{O}$ emissions from managed soils, and $\mathrm{CO}_{2}$ emissions from lime and urea application. In Guidelines for National Greenhouse Gas Inventories. Vol. 4: Agriculture, Forestry and Other Land Use. H. S. Eggleston, L. Buendia, K. Miva, T. Ngara, and K. Tanabe, ed. National Greenhouse Gas Inventories Program, Institute for Global Environmental Strategies (IGES), Japan, 11.5-11.4. IPCC, Geneva, Switzerland.

IPCC. 2007. Climate Change 2007: Synthesis Report. Contribution of working Groups I, II and III to the Fourth Assessment Report of the Intergovernmental Panel on Climate Change (IPCC), Valencia, Spain. IPCC, Geneva, Switzerland.

ISO. 2006a. ISO 14040:2006: Environmental management-Life cycle assessment-Principles and framework. International Organisation for Standardization (ISO), Geneva, Switzerland.

ISO. 2006b. ISO 14040:2006: Environmental management—Life cycle assessment-Requirements and guidelines. International Organisation for Standardization (ISO), Geneva, Switzerland.

Jones, A. K., D. L. Jones, and P. Cross. 2014. The carbon footprint of lamb: Sources of variation and opportunities for mitigation. Agric. Syst. 123:97-107.

Kiefer, L., E. Bahrs, and R. Over. 2014. Die Vorzüglichkeit der Grünlandnutzung in der Milchproduktion. Potentielle Vorteile der Vollweidehaltung. Schriften der Gesellschaft für Wirtschafts- und Sozialwissenschaften des Landbaues 49:173-184.

Kristensen, T., L. Mogensen, M. T. Knudsen, and J. E. Hermansen. 2011. Effect of production system and farming strategy on greenhouse gas emissions from commercial dairy farms in a life cycle approach. Livest. Sci. 140:136-148.

LAZBW (Landwirtschaftliches Zentrum Baden Wuerttemberg). 2014. Grünlandberatung im Netz. http://www.gruenland-online.de.

Lewis, E., M. Deighton, B. O'Loughlin, B. O'Neill, C. Wims, D. O'Brien, F. Buckley, L. Shalloo, and M. O'Donovan. 2011. Towards reduced methane from grass-based Irish milk production systems. Emissionen der Tierhaltung. Treibhausgase, Umweltbewertung, Stand der Technik. KTBL-Tagung 6. Bad Staffelstein, Germany.

LFL (Landesanstalt für Landwirtschaft). 2012. Gruber Tabelle zur Fütterung der Milchkühe Zuchtrinder Schafe Ziegen, 35. ed. Bayerische Landesanstalt für Landwirtschaft, Weihenstephan. http://www.lfl. bayern.de/mam/cms07/publikationen/daten/informationen/p_ 36967.pdf (last accessed 18.08.13).

Lovett, D. K., L. Shalloo, P. Dillon, and F. P. O'Mara. 2006. A systems approach to quantify greenhouse gas fluxes from pastoral dairy production as affected by management regime. Agric. Syst. $88: 156-179$.

Lovett, D. K., L. Shalloo, P. Dillon, and F. P. O'Mara. 2008. Greenhouse gas emissions from pastoral based dairying systems: The effect of uncertainty and management change under two contrasting production systems. Livest. Sci. 116:260-274.

Naturland. 2014. Naturland Richtlinien Erzeugung. Accessed Mar. 1, 2014. http://www.naturland.de/fileadmin/MDB/documents/ Richtlinien_deutsch/Naturland-Richtlinien_Erzeugung.pdf.

Neufeldt, H., M. Schäfer, E. Angenendt, C. Li, M. Kaltschmitt, and J. Zeddies. 2006. Disaggregated greenhouse gas emission inventories from agriculture via a coupled economic-ecosystem model. Agric. Ecosyst. Environ. 112:233-240.

Nuthall, P. L. 2011. Farm Business Management: Analysis of Farming Systems. ACB International, Wallingford, UK.

O'Brien, D., L. Shalloo, F. Buckley, B. Horan, C. Grainger, and M. Wallace. 2011. The effect of methodology on estimates of greenhouse gas emissions from grass-based dairy systems. Agric. Ecosyst. Environ. 141:39-48.
O'Brien, D., L. Shalloo, C. Grainger, F. Buckley, B. Horan, and M. Wallace. 2010. The influence of strain of Holstein-Friesian cow and feeding system on greenhouse gas emissions from pastoral dairy farms. J. Dairy Sci. 93:3390-3402.

Pirlo, G. 2012. Cradle-to-farm-gate analysis of milk carbon footprint: A descriptive review. Ital. J. Anim. Sci. 11(e20):109-118.

ProBas. 2013. Prozessorientierte Basisdaten für Umweltmanagement-Instrumente. Datenbank des Umweltbundesamtes der Bunderepublik Deutschland, Berlin, Germany.

Reijs, J. W., C. H. G. Daatselaar, J. F. M. Helming, J. Jager, and A. C. G. Beldman. 2013. Grazing dairy cows in north-west Europe. Economic farm performance and future developments with emphasis on the Dutch situation. Report of the Landbouw Economisch Instituut (LEI). LEI Wageningen UR,, Wageningen, the Netherlands.

Rotz, C. A., F. Montes, and D. S. Chianese. 2010. The carbon footprint of dairy production systems through partial life cycle assessment. J. Dairy Sci. 93:1266-1282.

Schils, R. L. M., A. Verhagen, H. F. M. Aarts, and L. B. J. Sebek. 2005. A farm level approach to define successful mitigation strategies for GHG emissions from ruminant livestock systems. Nutr. Cycl. Agroecosyst. 71:163-175.

Smith, P., D. Martino, Z. Cai, D. Gwary, H. Janzen, P. Kumar, B. McCarl, S. Ogle, F. O'Mara, C. Rice, B. Scholes, O. Sirotenko, M. Howden, T. McAllister, G. Pan, V. Romanenkov, U. Schneider, and S. Towprayoon. 2007. Policy and technological constraints to implementation of greenhouse gas mitigation options in agriculture. Agric. Ecosyst. Environ. 118:6-28.

Sutter, M., T. Nemecek, and P. Thomet. 2013. Vergleich der Ökobilanzen von stall- und weidebasierter Milchproduktion. Agrarforsch. Schweiz 4:230-237.

Thomassen, M. A., M. A. Dolman, K. J. van Calker, and I. J. M. de Boer. 2009. Relating life cycle assessment indicators to gross value added for Dutch dairy farms. Ecol. Econ. 68:2278-2284.

Thomassen, M. A., K. J. van Calker, M. C. J. Smits, G. L. Iepema, and I. J. M. de Boer. 2008. Life cycle assessment of conventional and organic milk production in the Netherlands. Agric. Syst. 96:95-107.

Thomet, P., E. Cutullic, W. Bisig, C. Wuest, M. Elsaesser, S. Steinbergerand, and A. Steinwidder. 2011. Merits of full grazing systems as a sustainably and efficient milk production strategy. Pages 273-285 in Proc.16th Europ. Grassl. Fed. Symp., Irdning, Austria. Organising Committee Agricultural Research and Education Centre (AREC) Raumberg-Gumpenstein, Irdning, Austria.

van der Werf, H. M. G., C. Kanyarushoki, and M. S. Corson. 2009. An operational method for the evaluation of resource use and environmental impacts of dairy farms by life cycle assessment. J. Environ. Manage. 90:3643-3652.

Waghorn, G. C., and R. S. Hegarty. 2011. Lowering ruminant methane emissions through improved feed conversion efficiency. Anim. Feed Sci. Technol. 166-167:291-301.

Weiss, F., and A. Leip. 2012. Greenhouse gas emissions from the EU livestock sector: A life cycle assessment carried out with the CAPRI model. Agric. Ecosyst. Environ. 149:124-134.

Yan, M.-J., J. Humphreys, and N. M. Holden. 2011. An evaluation of life cycle assessment of European milk production. J. Environ. Manage. 92:372-379.

Yan, T., C. S. Mayne, F. G. Gordon, M. G. Porter, R. E. Agnew, D. C. Patterson, C. P. Ferris, and D. J. Kilpatrick. 2010. Mitigation of enteric methane emissions through improving efficiency of energy utilization and productivity in lactating dairy cows. J. Dairy Sci. 93:2630-2638.

Zehetmeier, M., J. Baudracco, H. Hoffmann, and A. Heißenhuber. 2012. Does increasing milk yield per cow reduce greenhouse gas emissions? A system approach. Animal 6:154-166. 